\title{
THE ROLE OF INVESTMENT OPPORTUNITIES, MANAGERIAL OWNERSHIP, CAPITAL STRUCTURE ON CORPORATE VALUE
}

\author{
Darlene Dacia Septiana, Ernie Riswandari \\ Universitas Bunda Mulia \\ eriswandari@bundamulia.ac.id
}

\begin{abstract}
There are still companies that pay less attention and maintain value of ownership even though this is a concern in making investment decisions. In this study will examine investment opportunities, capital structure, and managerial ownership of firm value. The sample used is the financial statements of 27 companies manufacturing consumer goods sub sector in 2015-2017. This research is an associative research using secondary data which is quantitative data. Data is processed using Stata 12 by using multiple linear regression tests. The results showed that investment opportunities, capital structure, and managerial ownership had a significant effect on the firm's value partially on companies manufacturing the consumer goods sub sector.
\end{abstract}

Keywords: Company value, investment opportunity set, capital structure, ownership managerial

\section{INTRODUCTION}

In investing, investors not only have short-term goals, but also gain long-term income. Investors will use all the information to analyze the market and invest in hopes of making a profit. The company will make every effort to maintain company performance and increase the company's performance so that it will have an impact on the company's value.

There are still many companies that have problems with the value of the company which is marked by a decline in the share price of the company in the capital market, such as that experienced by PT Bakrie \& Brothers Tbk and PT
Campina Ice Cream Industry Tbk where the stock prices of the two companies have decreased due to due to poor performance triggered by company debt problems and a decline in sales (cnbcindonesia.com).

The company's efforts to increase company value are predicted to be caused by the selection of a series of investment opportunities or commonly called the Investment Opportunity Set (Handriani \& Irianti, 2015). Investment opportunities will affect the stock market price because investment opportunities will be received as a positive signal by investors (Suwartawan \& Yasa, 2016). Manager's interests that conflict with company goals can interfere with the 
EAJ (Economics and Accounting Journal) - Vol. 3, No. 2, May 2020 - Septiana \&

Riswandari

performance and sustainability of a company's business so that it will affect the value of the company. Conflicts between managers and shareholders can be minimized by a supervisory mechanism that can align these interests. With managerial share ownership it is expected that managers will behave in line with shareholders and will be motivated to always maintain and improve the performance of the company so that the company's value will increase. Managerial ownership has two different roles. First, the manager acts as a shareholder, and secondly acts as the manager of the company that carries out the company's operational activities. Such roles can affect the manager's performance at work and can trigger a desire to maintain a position in a company (Anggarini and Ceacilia, 2009) in ( Samisi \& Ardiana, 2013).

According to Lubis, Sinaga and Sasongko (2017) the capital structure of a company will affect the value of the company, where the capital structure is the ratio between the amount of longterm debt with share capital. The composition of the best capital structure for a company is one that can optimize the balance between risk and return.

The research question in this study is whether there is a significant influence of investment opportunities, capital structure and managerial ownership on the value of a company partially?

\section{LITERATURE REVIEW}

\section{Firm Value}

The price formed due to the demand and supply of shares of certain companies in the capital market can reflect the investor's assessment of the company value of the company that issued the shares. The higher the company's stock price is received by investors as a positive signal to the performance of the company. And the high market price of a company's shares reflects the high wealth owned by the company so that investors believe that the company has good prospects (Harmono, 2009).

\section{Investment Opportunities}

Investment opportunities are choices for making future investments that will be a component of company value (Smith and Watts, 1992 in Handriani \& Irianti, 2015). whereas according to Myers (1997) alternative investment decisions chosen by a company based on assets owned and investment choices to be made in the future are indicated by a positive Net Present Value (NPV) so that it affects the value of the company. Investment choices are expected to produce greater returns (Gaver and Gaver, 1993).

\section{Capital Structure}

The source of funding from a company can come from share capital and debt. The composition of capital owned by a company from the funding source is called the capital structure (Rodoni and Ali, 2010) where the company must be able to consider the risks that will be faced from choosing the composition of the funding source.

\section{Managerial ownership}

Agency conflict occurs because of the separation of company ownership and those who carry out the company's operational activities. but these conditions will be different if the management participates in the ownership of shares in the company. Companies with managerial ownership, as shareholders will certainly align their interests as managers and shareholders. This will be different if the manager is not at the same time a shareholder, it is likely that the manager is only concerned 
EAJ (Economics and Accounting Journal) - Vol. 3, No. 2, May 2020 - Septiana \& Riswandari

with his interests as a manager (Hidayah

(2015)

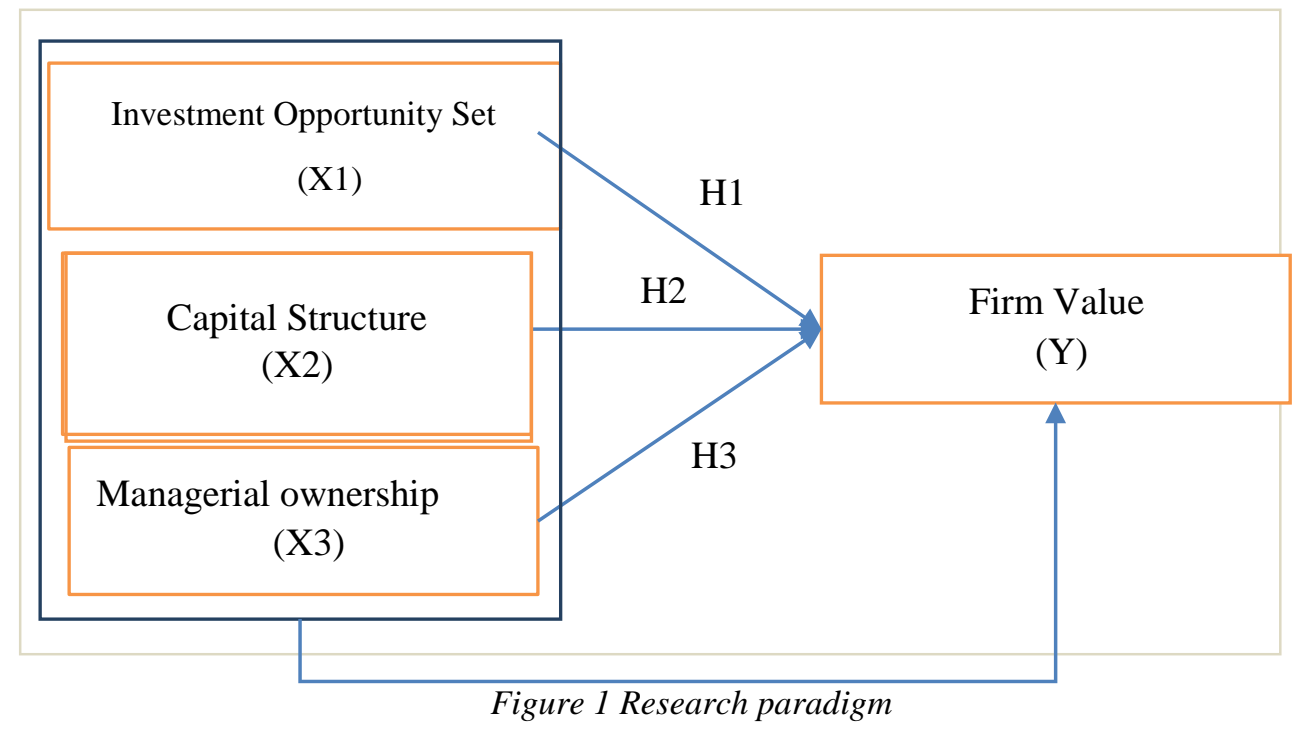

\section{Hypothesis Development}

\section{The Role of Investment Opportunities in Firm Value}

Myers (1997) states that investment opportunities provide broader guidance where the value of the company will depend on company expenditures determined by management, and is an investment expected to obtain a greater return in the future. Investor confidence in companies that take investment policies in high amounts will result in an increase in demand for company shares. the investment opportunity will give an idea of the condition of the company in the future. Research by Pratiska (2012) states that the company's value of a company is influenced by investment opportunities that the company will carry out. Then the hypothesis can be drawn as follows:

Hal: There is a significant influence of investment opportunities on firm value.

\section{Role of Capital Structure on Firm Value}

A company tends to optimize its capital composition which will provide a low capital cost. The most optimal and best capital composition that can provide an efficient capital cost for each company is not the same depending on the policy of the company by considering the level of risk that will be faced (Dewi \& Wirajaya, 2013). According to Chowdhury and Chowdhury (2010) the capital structure of a company will affect the value of the company because the capital structure owned by the company will affect the stability of the company's operational activities because of the choice of funding sources so that it will have an impact on performance so that it will have implications on the firm value. hypothesis as follows:

Ha2: There is a significant influence of capital structure on firm value.

\section{Effect of Managerial Ownership on Company Value}

The amount of share ownership by the management of all the company's share capital that is managed is called managerial ownership. According to 
EAJ (Economics and Accounting Journal) - Vol. 3, No. 2, May 2020 - Septiana \& Riswandari

Gideon (2005) in Jusriani \& Rahardjo (2013) the ownership of the shares is calculated based on the comparison of the number of shares owned by the company management that actively participates in company decision making with the number of shares outstanding.

According to Samisi \& Ardiana (2013), the separation of management functions and ownership functions within a company can trigger the emergence of agency conflict within the company. will have an impact on the value of the company. Based on the description above, then the hypothesis can be drawn as follows:

\subsection{Operational Definitions of Variables}

Table 1 : Operationalization of Variables
Ha3: There is a significant influence of managerial ownership on firm value.

\section{RESEARCH METHOD}

\subsection{Data Collection Techniques}

Investment opportunities, capital structure, and managerial ownership of firm value are the objects of this study. While the research subjects of this study are manufacturing companies engaged in consumer goods listed on the Indonesia Stock Exchange in 2015 -2017. Data obtained from the company's financial statements.

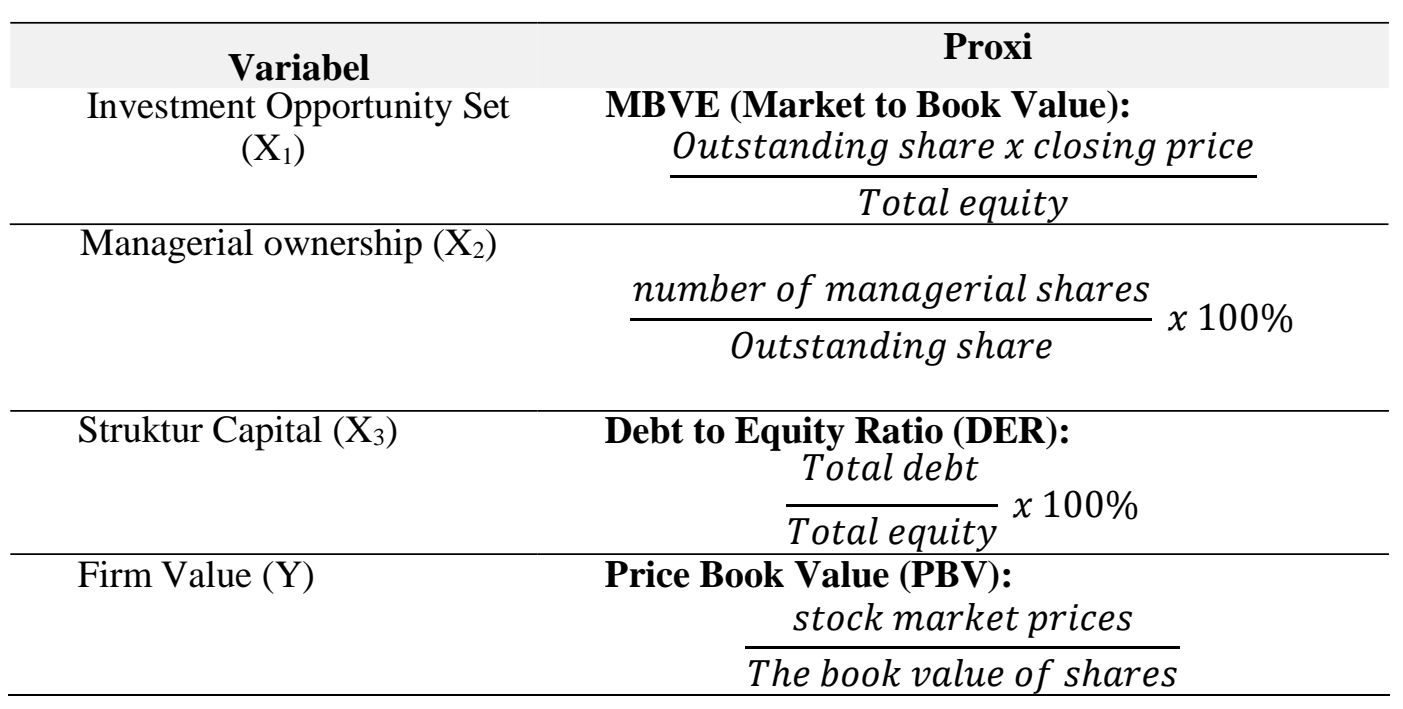

\subsection{Sample Collection Techniques}

The total population in the manufacturing industry sector engaged in the consumer goods sub sector listed on the Indonesia Stock Exchange in the period 2015-2017 there were 41 companies. The sampling technique used is to use a purposive sampling method that is the selection of samples based on predetermined criteria, based on this, the number of companies that meet the criteria of 27 companies is obtained as the sample used in this study.

\subsection{Data Analysis Techniques}

Data were tested using multiple linear regression tests using Stata 12 which had previously passed the classic assumption test consisting of normality test, Autocorrelation test, Multicolli-nearity Test and Heterokedasticity Test. 
EAJ (Economics and Accounting Journal) - Vol. 3, No. 2, May 2020 - Septiana \& Riswandari

\section{RESULTS AND DISCUSSION}

\subsection{Results}

Table 2 : Descriptive Test

\begin{tabular}{l}
. summarize \\
Variable \\
\hline TAHUN
\end{tabular}

Table 3 : Regression Test

- regress PBV IOS KepemilikanManajerial DER

\begin{tabular}{|c|c|c|c|c|c|c|c|}
\hline Source & SS & $\mathrm{Df}$ & MS & Number of & obs & $=$ & 81 \\
\hline- & & & . & $F(3$, & 77) & $=$ & 10.90 \\
\hline Model & .074584441 & 3 & .02486148 & Prob $>F$ & & $=$ & 0.0000 \\
\hline Residual & .17561062 & 77 & .002280657 & R-squared & & $=$ & 0.2981 \\
\hline-0 & & & "- & Adj R-squa & ared & $=$ & 0.2708 \\
\hline Total & .250195062 & 80 & .003127438 & Root MSE & & $=$ & .04776 \\
\hline
\end{tabular}

\begin{tabular}{|c|c|c|c|c|c|c|}
\hline PBV & Coef. & Std. Err. & t & $P>|t|$ & [95\% Conf. & Interval] \\
\hline & & & & & 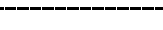 & -- \\
\hline IOS & .0079612 & .0035012 & 2.27 & 0.026 & .0009894 & .0149331 \\
\hline KepemilikanManajerial & .0156244 & .0064583 & 2.42 & 0.018 & .0027644 & .0284844 \\
\hline DER & .0103031 & .0051023 & 2.02 & 0.047 & .0001431 & .0204632 \\
\hline _cons & 2.202224 & .0135819 & 162.14 & 0.000 & 2.175179 & 2.229269 \\
\hline
\end{tabular}

\section{T Test}

Statistical test results here can beseen in table 3 by looking at the $t$ test (partial test). Partial test results show significant results at the level of $5 \%$ if $\mathrm{P}>[\mathrm{t}]$ or also called $\mathrm{p}$ value / significance $<0.05$. Based on these data it can be said that partially each variable significantly influences the PBV variable.

The value of $\mathrm{P}>[\mathrm{t}]$ on the IOS variable here is $0.026<0.05$, so it can be said that the IOS variable is significant and influences the PBV variable. In the Managerial Ownership variable, the value of $\mathrm{P}>[\mathrm{t}]$ is $0.018<0.05$ which means that there is a significant relationship to the PBV variable. Likewise in the DER variable, the value of $\mathrm{P}>[\mathrm{t}]$ is $0.047<0.05$, which means that it significantly influences the PBV variable.

\section{F Test}

Prob $F$ value of 0,000 , which means all independent variables jointly affect the dependent variable. This shows that together the IOS variables, Managerial Ownership and DER significantly influence the PBV variable.

\section{Multiple Linear Regression Test}

Obtained the following regression equation $\mathrm{Y}=2.202+0.007 \mathrm{X} 1+0.015$ $\mathrm{X} 2+0.010 \mathrm{X} 3+$ e. Where $\mathrm{Y}$ is $\mathrm{PBV}$ variable, 2,202 is constant, $\mathrm{X} 1$ is IOS variable, X2 is Managerial Ownership 
EAJ (Economics and Accounting Journal) - Vol. 3, No. 2, May 2020 - Septiana \&

Riswandari

variable, $\mathrm{X} 3$ is DER variable and e is error. The probability value of each variable is $<0.05$, indicating that all independent variables have a causal relationship with PBV variables.

\section{Determination Test (R2)}

The R-Squared Test is the Multiple Determination Coefficient, amounting to 0.2983 which shows that theindependent variables tested in this study only affect the dependent variable by $29.83 \%$.

\subsection{Discussion}

\section{Rule of investment opportunity on firm value}

Investment opportunity variable proxied by the Investment Opportunity Set (IOS) has a significant effect on firm value variables that are proxied with Price Book Value (PBV), both simultaneously with other variables or partially, showing that IOS significantly influences the value of the company (Sudiani and Darmayanti, 2016), (Suwartawan \& Yasa, 2016). IOS provides an overview of investment opportunities made by a company, but it is very determined on corporate expenditures that provide benefits in the future. So the Investment Opportunity Set affects the value of the company (Hidayah, 2015).

\section{Role of capital structure on firm value}

Firm value is influenced by company structure, the results of the study are in line with research conducted by Prastuti \& Sudiartha (2016) that firm value is significantly positively related to company structure. investors will pay attention to the capital structure of the company before deciding to invest in the company because the composition of the selection of funding sources owned by the company will have an influence on the stability of the company's operational activities which will affect the achievement of the company's performance and have implications for the value of the company (Fahmi, 2014). Thus for a company it is very important to strengthen its financial stability, because changes in capital structure are thought to cause changes in the value of the company.

\section{Rule of Managerial Ownership on Company Value}

Managerial ownership has a significant positive effect on firm value. according to Fritz Kleinsteuber $(2004,313)$ in (Muktiajdi \& Felicia, 2013) also revealed that the factors that are able to influence the value of the company include internal and external factors. internal factors here one of which is managerial ownership. These results are in line with research conducted by Ningsih (2013) that firm value is positively and significantly affected by managerial ownership. This is consistent with the results of research by Abbas (2013) and Abdolmanafi (2013) that increasing managerial ownership has a positive impact on firm value.

\section{CONCLUSION}

Investment opportunities have a positive and significant impact on the value of Manufacturing Companies in the consumer goods sub sector. So it can be interpreted that investment spending that will provide benefits in the future is interpreted by investors as something good because the company will continue to grow in the future. With the investment opportunity, it means that at this time the company's performance is considered good by investors because the company is considered to have the ability to manage its finances well besides the company is able to finance its operational activities it turns out that the company is also able to make investment expenditures that are 
EAJ (Economics and Accounting Journal) - Vol. 3, No. 2, May 2020 - Septiana \&

Riswandari

considered beneficial in the future and later on from the investments made will further support the company in achieving company performance which will later have an impact on the company's value.

Capital structure has a positive and significant influence on firm value in the manufacturing industry sub-sector of consumer goods. This shows that capital structure with a good and efficient composition will be accepted by investors as positive information because the company's funding sources are well managed so that it will affect the value of the company.

Managerial ownership has a positive and significant effect on Company Value. Managerial ownership can affect the course of company activities because management also has a stake in the company so that managerial ownership will be able to equalize the interests between management and shareholders which will ultimately affect the company's performance which will have an impact on the company's value.

\section{REFERENCES}

Abbas, Asad. (2013). Impact of Large Ownership on Firm Performance: A Case of non-Financial Listed Companies of Pakistan. World Applied Sciences Journal, 21 (8), 1141-1152.

Abdolmanafi, Saeed. (2013). The Effect of Managerial Stock Ownership on The Value of Listed Companies in Tehran Stock Exchange. Advances in Environmental Biology, 7(8), 1612-1615.

Chowdhury, Anup dan S.P. Chowdhury. (2010). Impact of Capital Structure on Firm's Value: Evidence from Bangladesh. Business and Economic Horizons, 3, 111-122.

cnbcindonesia.com
The value of a company owned by a company is the value given by the market through the market price of shares sold in the capital market because investors see the performance of the company. A company that has good performance and continues to increase is accepted by investors as a sign that the company has good prospects in the future so that investors are willing to buy shares of the company at a high price so that this has implications for the business continuity of a company because it gets trust or legitimacy from investors.

The number of samples used only in manufacturing companies in the consumer goods industry sub-sector makes this a limitation in this study. It is recommended that the next researcher expand the number of samples used and also add other independent variables so as to strengthen the results of research on the importance of paying attention and maintaining firm value.

Dewi, A. M., \& Wirajaya, A. (2013). Pengaruh Struktur Modal, Profitabilitas, dan Ukuran Perusahaan pada Nilai Perusahaan. E-Jurnal Akuntansi Universitas Udayana .

Fahmi, I. (2014). Pengantar Manajemen Keuangan Teori dan Soal Jawab. Bandung: Alfabeta.

Gaver, J.J, dan Gaver, K.M. (1993) "Additional Evidence on The Association Between The Irrvestment OpporlLrnity Set ar,d Corporate Financing Dividend, and Compesation Policies", Journal of Accounting and Economic, 125-160.

Harmono, 2009. Manajemen Keuangan. PT Bumi Aksara. Jakarta 
EAJ (Economics and Accounting Journal) - Vol. 3, No. 2, May 2020 - Septiana \&

Riswandari

Handriani, E., \& Irianti, T. E. (2015). Investment Opportunity Set (IOS Berbasis Pertumbuhan Perusahaan dan Kaitannya dengan Upaya Peningkatan Nilai Perusahaan. Jurnal Ekonomi dan Bisnis, 18(1), 83-99.

Hidayah, N. (2015). Pengaruh Investment Opportunity Set (IOS dan Kepemilikan Manajerial terhadap Nilai Perusahaan pada Perusahaan Property dan Real Estate di Bursa Efek Indonesia. Jurnal Akuntansi, 19(3), 420-432.

Jusriani, I. F., \& Rahardjo, S. N. (2013). Analisis Pengaruh Profitabilitas, Kebijakan Dividen, Kebijakan Utang, dan Kepemilikan Manajerial terhadap Nilai Perusahaan (Studi Empiris pada Perusahaan Manufaktur yang Terdaftae di Bursa Efek Indonesia Periode 2009-2011. Diponegoro Journal of Accounting, 1-10.

Lubis, I. L., Sinaga, B. M., \& Sasongko, H. (2017). Pengaruh Profitabilitas, Struktur Modal, dan Likuiditas terhadap Nilai Perusahaan. Jurnal Aplikasi Bisnis dan Manajemen, 3(3), 458465

Muktiajdi, N., \& Felicia. (2013). Analisis Kebijakan Dividen terhadap Nilai Intrinsik dan Nilai Pasar Perusahaan. Jurnal Ilmiah Manajemen Kesatuan, 1(2), 113124.

Myers, Stewart C. (1997), Determinant of Corporate Borrowing, Journal of Financial Economics, 5, 147175

Ningsih, R. (2013). Pengaruh Kepemilikan Manajerial Terhadap
Nilai Perusahaan (StudiKasus pada Industri Perbankkan yang terdaftar di BEI). Jurnal Universitas Komputer Indonesia.

Prastika, Ni Gst. A. Pt. Silka. 2013. "Pengaruh IOS, Leverage, Dan Dividend Yield Terhadap Profitabilitas Dan Nilai Perusahaan Sektor Manufaktur Di BEI.” Jurnal Ekonomi Dan Bisnis Universitas Udayana, 1, 147-74.

Prastuti, N. R., \& Sudiartha, I. M. (2016). Pengaruh Struktur Modal, Kebijakan Dividen, dan Ukuran Perusahaan terhadap Nilai Perusahaan pada Perusahaan Manufaktur. E-Jurnal Manajemen Unud, 5(3)

Rodoni, Ahmad dan Ali, Herni. (2010), Manajemen Keuangan. Jakarta: MitraWacana Media.

Samisi, K., \& Ardiana, P. A. (2013). Pengaruh Struktur Pendanaan terhadap Nilai Perusahaan dengan Kepemilikan Manajerial Sebagai Variabel Moderasi. E-Jurnal Akuntansi Universitas Udayana, 5 , (2), 451-469.

Suartawan, I. A., \& Yasa, G. W. (2016). Pengaru Investment Opportunity Set dan Free Cash Flow pada Kebijakan Dividen dan Nilai Perusahaan. E-Jurnal Akuntansi Universitas Udayana, 14(3), 2014-2044

Sudiani, N. A., \& Darmayanti, N. A. (2016). Pengaruh Profitabilitas, Likuiditas, Pertumbuhan, dan Investment Opportunity Set terhadap Nilai Perusahaan. EJurnal Manajemen Unud, 5(7), 4545-4574. 